\title{
NUTRITION IN AGRICULTURAL DEVELOPMENT: INTENSIVE DAIRY FARMING BY RURAL SMALLHOLDERS
}

\author{
JAN HOORWEG ${ }^{1,2, *}$, PIET LEEGWATER ${ }^{3}$ \\ and WILLEM VEERMAN ${ }^{1}$ \\ ${ }^{1}$ African Studies Centre, Leiden, Netherlands; \\ ${ }^{2}$ Coast Environment Research Station, Moi University, \\ P.O. Box 710, Malindi, Kenya; \\ ${ }^{3}$ International Agricultural Centre, Wageningen, Netherlands
}

(Received May 6, 1996; in final form March 3, 2000)

This study concerns the introduction of intensive dairy farming among rural smallholders in Killifi District, Kenya. Household surveys were conducted among dairy farmers, dairy customers and a comparison sample from rural locations. Dairy farmers were better off than the rural sample as regards household income, food production, food consumption and nutritional status of young children. These differences resulted from the dairy activities but also from greater involvement in crop cultivation and off-farm employment.

Local milk purchases by dairy customers were mostly by wealthier households with wage employment. They had higher incomes and higher food consumption than the rural sample, and the children in these households had better nutritional status. Further analysis confirms a positive relation between milk consumption and nutritional status of children, independent of household income, energy intake and level of education. Other notable findings were the high incomes from off-farm employment of dairy farmers; regular dairy customers are chiefly households with wage employment; milk consumption among the rural population was very low.

The results cast doubt on the importance of intensive dairy production as a means of livelihood for resource-poor households and the importance of milk as a means to improve nutritional status of children in low-income households.

KEY WORDS: Agricultural development, rural development, dairy farming, household income, milk consumption, nutritional status, Kenya

*Corresponding author. 


\section{INTRODUCTION}

Agricultural development is one of the main priorities for the countries of Sub-Saharan Africa. To increase agricultural production, supportive agricultural policies are needed as well as improvements in farming practices and intensification of production. The expectation of planners and development workers alike has been that such changes would lead to increased farm production which, in turn, would result in increased household incomes and higher living standards. However, evidence emerged that increases in productivity may actually occur at the expense of living conditions of the farming population (Fleuret and Fleuret, 1980).

There has since been concern about the effects of agricultural commercialisation on poverty and nutrition in developing countries. Opponents have argued that land and labour are taken away from food production, income gains tend to be skewed and do not reach the poor, and there are adverse economic developments such as possible rise in food prices. Proponents have pointed to the comparative economic advantage of cash crops for many tropical countries, income opportunities that are created for smallholders, as well as employment opportunities for the landless (Pinstrup-Andersen, 1985). Effects on income and employment, food consumption and health and nutrition have been investigated (Braun and Kennedy, 1994). Agricultural development may have positive as well as negative consequences for food and nutrition conditions depending on the manner in which available resources are utilised. Hence, there is need for studies on different kinds of agricultural development under different conditions (Niemeijer et al., 1988; Hoorweg et al., 1996).

Most studies have been concerned with "export" or "cash" crops that are often not suitable for home consumption. Dairy farming is an exception because it entails the production of a high-quality food that can be used for sales as well as for home consumption. If used for home consumption, milk is important for young children and pregnant and lactating mothers. If sold, milk sales provide a steady, daily flow of income; quite different from the usual bulk payments for most cash crops. Furthermore, if sold, milk sales for local consumption may benefit other households in the community, 
potentially contributing to the improvement of nutritional conditions of farmers and customers alike. This paper describes what happens when intensive dairy production is started among smallholder farmers. It reports on the income levels and nutritional conditions of dairy farmers and their local customers in Kilifi District in the Coast Province of Kenya. ${ }^{1}$

\section{Kenya and Coast Province}

Kenya, despite its image as a fertile country is, in fact, short of good agricultural land (Ruigu, 1987). Only $20 \%$ of the land area consists of high and medium potential lands, most of which are already under cultivation. Production increases mainly depend on the possibilities of bringing remaining, often marginal, areas under cultivation and on intensification of crop cultivation and livestock production (Kenya, 1986b).

Coast Province is one of three main areas of population concentration in Kenya, together with Central and Western Provinces. There were more than 1.8 million inhabitants at the time of the latest census in 1989 (Kenya, 1994). The climatic and economic conditions are quite different from those of the highland areas. Rainfall in Coast Province is bi-modal in nature: long rains in the period April-June and short rains in October-November. The climate is hot and dry from December to April, when daily temperatures average more than $30^{\circ} \mathrm{C}$. The fertility of the land tends to be low because most soils are chemically poor (Boxem, Meester and Smaling, 1987). The coastal plain and adjoining uplands have potential for food and cash crop production. Further inland, conditions are drier and allow for mixed farming of food crops and livestock. The sparsely populated hinterland is suitable for ranching (Jaetzold and Schmidt, 1983; Waaijenberg, 1994).

Previously, the economy was primarily dependent on agriculture, the cultivation of food crops (cereals, cassava) and tree crops (coconut palms, cashew trees). The seasonal character and low reliability of rainfall, however, severely restrict the scope and

\footnotetext{
${ }^{1}$ The study was part of a larger research programme examining rural conditions in the coastal lowlands between 1985 and 1987 (see Hoorweg, 1993).
} 
productivity of agriculture while the short rains are often insufficient for a second crop. Farming practices in general are labour-intensive and little modernised (Waaijenberg, 1993; Oosten, 1989). Drought conditions are not uncommon (Herlehy, 1984; Kliest, 1985; Waaijenberg, 1993). Wage employment has increased in importance although the industrial and services sectors have developed slowly in comparison with central and western Kenya, the tourist sector being an exception (Kenya, 1984a; 1984b).

Coast Province ranks low on development indicators such as infant mortality, childhood malnutrition, and enrollment of girls in primary education. Estimates place the incidence of rural poverty at $40 \%$ of the households or more, which is higher than in Kenya as a whole (Kenya, 1983; 1988; UNICEF, 1984; Greer and Thorbecke, 1986; Hoorweg, Foeken and Klaver, 1995).

\section{Dairy Development in Kilifi District}

Coast Province had five districts at the time of study; Kilifi District $^{2}$ accounted for about a third of the coastal population with the large majority being of Mijikenda origin. Agro-ecological conditions are typical for the province, ranging from coastal plain to inland ranching zone. In the drier parts livestock always offered an important means of subsistence. At the time of study, the cattle population was estimated at about 213,000 head, of which about 13,000 were improved breeds (Kenya, 1986a). Most of the local cattle-small East African Zebu-are found in the hinterland under traditional systems of animal husbandry. In the hilly range nearer the coast and in the coastal plain some herds were present on large- and medium-size farms. These herds were generally small in size, consisting of exotic breeds and grade (crossbred) animals. A few smallholders also owned grade cattle. The modern dairy enterprises processed at the farm and sold to shopkeepers or customers at their own distribution centres. Some delivered part of their production to the Kenya Cooperative Creameries (KCC). At the time, $\mathrm{KCC}$, the paragov-

\footnotetext{
${ }^{2}$ In January 1997 the district was subdivided into Kilifi and Malindi Districts; this paper refers to the original undivided district.
} 
ernmental organization charged with dairy marketing, had two plants near Mombasa which produced mainly for the school milk programme and the urban market (one of the plants produced reconstituted milk). Most smallholders sold directly to households, shops, (local) hotels, or to hawkers at prices usually quite close to those of the packaged $\mathrm{KCC}$ milk. The price in the hinterland was much lower, and part of the production was used to make ghee (clarified butter), which was sold in coastal towns. Existing information indicated that milk production and consumption levels in Kilifi District were generally low (Kenya, 1981, 1983; Niemeijer, Foeken and Klaver, 1991; Hoorweg et al., 1991). In 1985 , milk production was estimated at 56,200 litres per day, the farms with improved breeds accounting for $55 \%$, local herds for 45\% (Leegwater, Ngolo and Hoorweg, 1991). But this figure hides seasonal fluctuations in production which are more pronounced in the local herds.

The national Dairy Development Project (DDP), was started in 1980 (Kenya, 1986a). The project received financial and manpower support from the Netherlands Government for a number of years; in 1995 this support came to an end. The principal objective of the project was to improve dairy management practices on mixed smallholder farms with the introduction of (so-called) zero-grazing, in which cattle are kept permanently in stable. The main requirements to make the system viable are cultivation of fodder crops and an adequate supply of water, which both have to be brought to the animals. This production system is labourintensive but assures a regular income throughout the year while output compared favourably with that of cash crop cultivation (Valk, 1985; Mwangi et al., 1986). Since few individual farmers owned improved breeds, DDP-participants usually had to purchase suitable animals so the investment costs were high. Consequently new participants had to meet certain criteria concerning land ownership, income and farming ability. Apart from helping participants to obtain loans as start capital the project provided extension support together with $\mathrm{AI}$ and veterinary services.

Most DDP-activities were in the highland areas with good potential for dairy farming and already existing dairy experience. Activities were also started in some of the drier and hotter areas, 
such as Kilifi District, with a lesser potential for dairy farming. In 1986 there was a total of 1,162 DDP-farms in Kenya with 72 DDP-farms in Kilifi District. The constraints in Kilifi District were quite different from those up-country. In general, more land was available, but soil fertility was lower and rainfall less reliable. Consequently fodder cultivation was more difficult and fodder conservation was necessary. The climate is favourable for tsetse flies and ticks that transmit bovine sleeping sickness (Trypanosomiasis) and East Coast Fever, respectively. Consequently, a more intensive system of disease control was required.

In Kilifi District, DDP-farms generally had better production results than other kinds of smallholder dairy farms and far better results than livestock herds further inland. Milk production per cow was higher (3.41, 0.61 and 0.2 litre/day, respectively), as well as milk production per farm (9.41, 5.11 and 3.8 litre/day). DDP farmers sold nearly $80 \%$ of their production and kept about 1.8 litre/day for home consumption. The other groups mentioned did sell about half the milk and kept 2.0-2.5 litres for home consumption. Most sales were to local consumers; DDP-farmers sold only a quarter of their production to destinations outside the location. ${ }^{3}$

\section{METHODS}

\section{Study Design}

Three groups of households were selected for study: DDP-farmers, fully operational participants in the Dairy Development Project who had started before $1985(N=30)$; dairy customers, one regular local client randomly selected from customers of each DDP-farmer included in the study $(N=24$, six farmers did not have regular local customers); a rural sample, consisting of farming households in two locations in central Kilifi and situated in the

\footnotetext{
${ }^{3}$ The information on milk production and milk sales was presented in the original report (Leegwater, Ngolo and Hoorweg, 1991) and will be published elsewhere (Leegwater and Hoorweg, in press).
} 
same agro-ecological zones where the dairy farmers are located $(N=90)$. For the latter group detailed data were available from surveys, one year earlier, that have been reported in Hoorweg, Foeken and Klaver (1995).

\section{Data Collection}

Information was collected during single visits in the period MayJune '87. The data schedule covered living conditions of the households, household size, demographic and employment characteristics, farm characteristics, food consumption and nutritional status of children. Information collected on living conditions consisted of housing characteristics and sanitation facilities. Demographic particulars included sex, age, marital status, education and occupation. Employment was specified by type and period of employment with a corresponding income classification. Farm characteristics queried were annual crops, perennials, tree crops and livestock, specifically milk production, milk sales and destination.

Food consumption was estimated with a 24-hour-recall of all food prepared in the compound during the day prior to the interview. In households with more than one kitchen, food preparation was recorded for each kitchen. The women concerned were questioned about all the foods and drinks they had prepared or served in the course of the previous day. Starting with the first dish of the day all subsequent dishes (including drinks and snacks) were determined. They were further asked to indicate cooking procedures used and to indicate the volumes of different ingredients used, as well as the total volume of the dish as finally prepared. In the case of leftovers from meals, the volume of food that had not been eaten was separately estimated and subtracted. ${ }^{4}$ For each ingredient it was further noted whether it was

\footnotetext{
${ }^{4}$ In some households visitors participated in meals, in other households some members had meals while visiting a friend or relative. A check in one of the companion studies revealed no systematic bias from this source: both visitors and outside meals cancel each other out statistically (Niemeijer, Foeken and Klaver, 1991).
} 
home-produced (subsistence) or not. The latter nearly always meant that it had been purchased. Energy and protein content were calculated with the food composition table of Platt (1962). Milk consumption was recorded for the most recent (nearest) day in the preceding two weeks that milk was consumed, together with information on origin and manner of consumption.

Nutritional status was assessed by means of anthropometry; height and weight were measured for children, 6-59 months of age. For children under two years weights were measured with a Salter 235 scale (maximum $25 \mathrm{~kg}$ with an accuracy of $100 \mathrm{~g}$ ) and heights were measured in supine position. For older children weights were measured with a Teraillon digital scale (maximum $135 \mathrm{~kg}$ with an accuracy of $200 \mathrm{~g}$ ) and heights were measured in upright position using microtoises fixed to a standing metal rod with a wooden footpiece.

\section{Data Analysis and Presentation}

Household size was calculated in terms of consumer units (c.u.): individuals were weighted on the basis of estimated nutritional requirements according to sex, age and assumed activity level as given by WHO (1985). One consumer unit equals a reference adult male of 20-29 years requiring $2,960 \mathrm{kcal} /$ day. This procedure, by its nature, corrects for differences in household composition.

Food self-sufficiency was calculated on the basis of the reported harvest of cereals, beans, cassava and banana for the previous year, with the assumption that $75 \%$ of total energy requirements is met by these staple foods. ${ }^{5}$

Household income was calculated in shilling/household/year and includes the net value of subsistence and cash crop production, livestock proceeds, and wages from various types of employment corrected for worker residence. (If not fully resident the wage

\footnotetext{
${ }^{5}$ That is, $2,220 \mathrm{kcal}$ per c.u. per day. This assumption was corroborated by the results of a nutrition survey in six coastal locations (Niemeijer, Foeken and Klaver, 1991). The contribution of the staple foods equalled $2,166 \mathrm{kcal}$, being $84 \%$ of the actual intake and $73 \%$ of the estimated requirements.
} 
income was only partly calculated as contributing to the household income.)

Nutritional status was expressed as percentages of the international reference values for height-for-age, weight-for-height and weight-for-age (WHO, 1983).

Differences between groups were tested by means of analysis of variance. Resulting $F$-values are included in the tables with degrees of freedom and level of significance. On one occasion, a paired $t$-test was calculated.

Given the similarity in outcomes for dairy farmers and dairy customers that will be shown later, the results of these groups were, on two occasions, pooled for statistical purposes.

\section{RESULTS}

Extended households were common, either because of polygamy, multigenerations and/or multihouseholds of the same generation living together. The number of extended households was considerably larger among dairy farmers than among the two other groups. Consequently, average household size was largest among this group (Table I). Household size was smallest among the rural sample. The dairy farmers were generally located within easy distance from the main roads and in the vicinity of water pipelines. The percentage of households with latrine facilities differed little between the groups. Among dairy farmers and dairy customers almost $50 \%$ of the men had attended one or more years of post-primary education. The figures were much lower among the rural sample.

\section{Household Resources}

The dairy farmers had more farm resources than the two other groups (Table I). Average farm size was larger, these farmers owned more commercial trees and-almost by definition-more cattle. At DDP-farms some of the crop land was planted with fodder grass or reserved for grazing. Most households had off-farm income. Employment was found in local trade, government services, 
TABLE I

Characteristics of dairy groups in Kilifi, Kenya (averages with standard deviation in brackets unless indicated otherwise)

\begin{tabular}{|c|c|c|c|c|}
\hline & & $\begin{array}{c}\text { Dairy } \\
\text { Farmers }\end{array}$ & $\begin{array}{c}\text { Dairy } \\
\text { Customers }\end{array}$ & $\begin{array}{l}\text { Rural } \\
\text { Sample }\end{array}$ \\
\hline \multicolumn{5}{|l|}{ Sample composition } \\
\hline Number of households & $(N)$ & 30 & 24 & 90 \\
\hline People/h.hold & & $14.9(8.0)$ & $10.5(9.4)$ & $10.0(5.1)$ \\
\hline Consumer units/h.hold & & $8.9(5.0)$ & $6.4(5.4)$ & $5.9(3.0)$ \\
\hline \multicolumn{5}{|l|}{ Living conditions } \\
\hline People/room & & $2.5(1.9)$ & $1.9(0.9)$ & $3.4(2.1)$ \\
\hline $\begin{array}{l}\text { Protected water source } \\
\text { in wet season }\end{array}$ & $(\%)$ & 83 & 100 & 59 \\
\hline Latrine present & $(\%)$ & 83 & 79 & 73 \\
\hline \multicolumn{5}{|l|}{ Educational level } \\
\hline $\begin{array}{l}\text { Men with more than } \\
\text { primary education }\end{array}$ & $(\%)$ & 45 & 47 & 18 \\
\hline Women (idem) & $(\%)$ & 22 & 18 & 3 \\
\hline \multicolumn{5}{|l|}{ Household resources } \\
\hline Farm size, ha & & $11.5(11.3)$ & $5.7(5.2)$ & $3.6(3.7)$ \\
\hline Cash crops, trees ${ }^{2}$ & & $617(1042)$ & $251(334)$ & $219(565)$ \\
\hline Livestock, cattle & & $7.3(9.0)$ & $1.5(5.2)$ & $0.4(2.2)$ \\
\hline Adults employed & (\%) & 24 & 31 & 20 \\
\hline
\end{tabular}

a Coconut, cashew, mango, citrus.

industries, the harbour of Mombasa and the tourist sector. The majority of workers were men. Among the three groups, dairy customers were the most often employed; half the household heads were employed by the government (14), self-employed (5), or worked in the private sector (2).

\section{Household Income}

The income of the dairy farmers was sh.42,290/year, among dairy customers it was sh.31,313, compared to sh.9,268 among the rural sample (that is, sh.770/month). ${ }^{6}$ The income composition

${ }^{6}$ At the time of study the exchange rate was about 16 Kenya shillings: 1 U.S. dollar. 
TABLE II

Household income by dairy group in Kilifi, Kenya (sh/household/year; averages with standard deviation in brackets)

\begin{tabular}{|c|c|c|c|}
\hline & $\begin{array}{c}\text { Dairy } \\
\text { Farmers } \\
(N=30)\end{array}$ & $\begin{array}{c}\text { Dairy } \\
\text { Customers } \\
(N=24)\end{array}$ & $\begin{array}{c}\text { Rural } \\
\text { Sample } \\
(N=90)\end{array}$ \\
\hline Food crops & $6,228 \quad(6,634)$ & $4,824 \quad(5,946)$ & $2,784 \quad(3,069)$ \\
\hline Cash crops & $6,564(12,875)$ & $3,454 \quad(6,079)$ & $3,311 \quad(8,926)$ \\
\hline Livestock & $13,099(9,955)$ & $360 \quad(936)$ & $(431)$ \\
\hline+ Farm income $e^{(a)}$ & $25,891(16,432)$ & $8,639(10,972)$ & $6,277 \quad(9,942)$ \\
\hline Regular employment* & $14,428(18,102)$ & $19,795(17,445)$ & $2,108 \quad(3,734)$ \\
\hline $\begin{array}{l}\text { Self-employment and casual } \\
\text { labour* }\end{array}$ & $4,970 \quad(9,578)$ & $2,879 \quad(6,074)$ & $882(1,501)$ \\
\hline+ Employment income*(b) & $19,398(18,697)$ & $22,674(18,815)$ & $2,990 \quad(4,002)$ \\
\hline Total/h.hold/year ${ }^{(c)}$ & $45,290(28,019)$ & $31,313(24,173)$ & $9,268(11,638)$ \\
\hline Total/consumer unit ${ }^{(\mathrm{d})}$ & $6,386(5,465)$ & $8,816(8,845)$ & $1,754(2,060)$ \\
\hline
\end{tabular}

*corrected for worker residence.

(a) $F(2,141)=31.93 ; p<0.001$.

(b) $F(2,141)=39.04 ; p<0.001$.

(c) $F(2,141)=47.62 ; p<0.001$.

(d) $F(2,141)=27.34 ; p<0.001$.

shows that dairy farmers had triple the farm income of the two other groups; largely because of their dairy income, although income from food crops and tree crops was also higher (Table II). Employment income was highest among the dairy customers. It was also high among the dairy farmers and, in fact, was slightly higher than their dairy income. The rural sample did lag behind in farm income and particularly in employment income.

Dairy farmers as well as dairy customers clearly belonged to the better-off households; the majority of the rural sample was poor with half the households below the food-poverty line. ${ }^{7}$ Income composition was most diverse among DDP-farmers. Income flow in these households could also be expected to be fairly regular because of daily milk sales.

\footnotetext{
${ }^{7}$ The food poverty line, in this case defined as the necessary purchasing power for a household energy supply sufficient to assure daily survival but with minimal activities $(2,115 \mathrm{kcal} / \mathrm{cu} / \mathrm{day})$.
} 
TABLE III

Food self-sufficiency, food consumption and milk consumption by dairy group in Kilifi, Kenya (averages with standard deviation in brackets unless indicated otherwise) ${ }^{*}$

\begin{tabular}{|c|c|c|c|c|c|c|}
\hline \multirow[b]{2}{*}{ Food self-sufficiency ${ }^{(a)}$} & \multirow[b]{2}{*}{$(\%)$} & $\begin{array}{c}\text { Dairy } \\
\text { Farmers } \\
(N=30)\end{array}$ & \multicolumn{2}{|c|}{$\begin{array}{c}\text { Dairy } \\
\text { Customers } \\
(N=24)\end{array}$} & \multicolumn{2}{|c|}{$\begin{array}{c}\text { Rural } \\
\text { Sample } \\
(N=86)\end{array}$} \\
\hline & & $78 \quad(91)$ & 64 & (79) & 48 & (43) \\
\hline \multicolumn{7}{|l|}{ Energy intake (kcal/c.u.) } \\
\hline Subsistence source ${ }^{(b)}$ & & $698 \quad(647)$ & \multicolumn{2}{|c|}{$398 \quad(719)$} & \multicolumn{2}{|c|}{$439 \quad(859)$} \\
\hline Purchase source $\mathrm{e}^{(\mathrm{c})}$ & & $1,954(1,006)$ & \multicolumn{2}{|c|}{$2,429(1,123)$} & \multicolumn{2}{|c|}{$2,199(1,066)$} \\
\hline Total $^{(d)}$ & & $2,652 \quad(949)$ & 2,827 & (984) & 2,637 & $(975)$ \\
\hline Protein intake (g/c.u. $)^{(\mathrm{e})}$ & & (35) & 84 & (37) & 68 & (30) \\
\hline \multicolumn{7}{|l|}{ Milk consumption } \\
\hline $\begin{array}{l}\text { Households with regular } \\
\text { milk intake }\end{array}$ & $(N)$ & 26 & \multicolumn{2}{|l|}{24} & \multicolumn{2}{|l|}{8} \\
\hline $\begin{array}{l}\text { Milk intake (grams/day/ } \\
\text { household) }\end{array}$ & & $1,385(1,154)$ & 980 & $(760)$ & 56 & (248) \\
\hline $\begin{array}{l}\text { Milk intake (grams/day/ } \\
\text { consumer unit) }\end{array}$ & & $200 \quad(199)$ & 249 & $(280)$ & 11 & (51) \\
\hline
\end{tabular}

*Energy requirements $2,960 \mathrm{kcal}$; protein recommendations $50 \mathrm{~g}$

(a) $F(2,137)=2.87 ; p=0.06$.

(b) $F(2,137)=1.37 ; p=0.26$.

(c) $F(2,137)=1.35 ; p=0.26$

(d) $F(2,137)=0.37 ; p=0.69$.

(e) $F(2,137)=2.35 ; p=0.10$.

(f) $F(2,141)=57.44 ; p<0.001$.

(g) $F(2,141)=33.90, p<0.001$

\section{Food Self-Sufficiency}

In general, food production in the region was insufficient to meet the needs of the local population (Hoorweg, Foeken and Klaver, 1995); the year of this study was no exception. The main food crops are maize, cassava, bananas and pulses. The DDP-farmers and DDP-customers did manage to grow sufficient food to cover three-quarters and two-thirds respectively of energy intake expected to come from staple foods (Table III), more than the 
amount determined among the rural sample, which was less than $50 \%$. The actual contribution of home production to food consumption at the time of study, however, was less, as is shown below.

\section{Energy and Protein Intake}

Diets in Kilifi District consist first and foremost of maize meal in the form of ugali (maize paste) or uji (thin maize porridge). Nearly all households consume at least one maize dish a day. Next in importance are cassava, green leaves and dried fish, but these are consumed less frequently and in much smaller amounts. Tomatoes and coconuts serve mostly as flavourings.

The energy intake of dairy customers was $2,827 \mathrm{kcal} / \mathrm{c}$.u./day; about $200 \mathrm{kcal}$ higher than that of the dairy farmers and the rural sample (Table III). A higher figure for the dairy customers is to be expected since they had relatively high incomes. The figure for the dairy farmers needs correction for the fact that their households were much larger in size than the customer households (14.9 vs. 10.5 persons). This tends to depress the individual intake figures. ${ }^{8}$ After correction for the latter effect the dairy farmers and dairy customers have similar energy intake levels. The rural sample remains more than $200 \mathrm{kcal}$ behind although this is not statistically significant because of the large standard deviations that occur, caused by irregular daily consumption, some families eating very little or almost nothing on the day of study. Protein intake in all groups was well above the safe level of $50 \mathrm{~g}$ edible protein, based on international recommendations (WHO, 1985).

The contribution of foods from own farm was low (Table III) and less than could be expected from the degree of food self-sufficiency that was calculated earlier. This discrepancy is due partly to the timing of the survey, shortly before the long rain crops were

\footnotetext{
${ }^{8}$ Two companion studies showed that household size is an important factor in determining energy intake. The figures of food consumption per person in large households was less than in small households, corresponding to a rate of about $70 \mathrm{kcal}$ per consumer unit (Hoorweg et al., 1991; Niemeijer, Foeken and Klaver, 1991). When results in Table III are adjusted to a household size of 6.0 consumer units, the corrected energy intake figures are respectively $2,855 \mathrm{kcal}$ (dairy farmers), $2,855 \mathrm{kcal}$ (dairy customers), $2,630 \mathrm{kcal}$ (rural sample).
} 
harvested. At this time of year large amounts of staple foods need to be purchased because other means, such as hunting, gathering, or gifts of food, are of little importance nowadays. More than three quarters of food energy was from purchased foods. Still, the contribution of home-grown foods was highest among the DDP-farmers with more than $25 \%$ (Table III). The DDP-customers purchased most of their food: more than $85 \%$, something they may have been able to afford because of their wage incomes. The rural comparison population also had to purchase most of its food (more than $80 \%$ ), although they could ill afford it, and they did eat less.

\section{Milk Consumption}

Nearly all dairy farmers and dairy customers reported regular milk consumption while this was the case for only $10 \%$ of the rural population (Table III). Nearly all households add milk to tea for consumption by adults and children. Among dairy farmers and customers milk was also used as a drink in many households (50\% and $70 \%$ of the cases, respectively), which is for the benefit of the children. Among the local (Mijikenda) population adults customarily do not drink undiluted milk (Kubo, 1999). Average milk consumption of DDP-farmers and DDP-customers was much higher than among the rural population. The farmer households consumed about 1.5 litre a day, customer households about 1.0 litre, but their consumption per person was higher (Table III). Milk consumption in the rural sample was quite low, an average of only $56 \mathrm{ml} /$ household/day. This low milk consumption was not because of lack of supply since milk could be purchased in nearly every village either directly from dairy farmers or from shops selling pasteurised milk from KCC. More likely, milk was too expensive, and this was indeed mentioned by respondents. Milk consumption per consumer unit varied from $249 \mathrm{~g}$ to $11 \mathrm{~g}$ per day if the milk was shared by adults and children. ${ }^{9}$

\footnotetext{
${ }^{9}$ However, it is likely that children were given more milk. For example, assuming that $75 \%$ of the milk goes to the children younger than 10 years, it can be estimated that average milk consumption of these children is $309 \mathrm{~g}$ (dairy farmers), $345 \mathrm{~g}$ (dairy customers), and $14 \mathrm{~g} /$ day (rural sample).
} 
Among the rural population, the correlations between household size, household income, household energy intake and milk consumption all were significant. There was a noteworthy correlation between energy intake and milk consumption $(r=0.47 ; p<0.01)$ which was also found among the combined group of dairy farmers and dairy customers $(r=0.43 ; p<0.01)$.

\section{Nutritional Status}

Table IV presents the nutritional status of the preschool children in the three groups. The children in the rural sample were behind on all indicators: height-for-age, weight-for-age and weight-for-height. Differences also existed in the percentage of children below respective cut-off points. Among the rural sample, $33 \%$ of the children were stunted (height-for-age $<90$ ) and $21 \%$ were wasted (weight-for-height $<85$ ). Among the children of DDP-farmers and DDP-customers these rates were 10-20 percentage points less.

There are notable differences in household income between the dairy farmers and customers on the one hand and the general population on the other, that must have influenced living conditions and nutritional status. To eliminate this confounding factor, as many pairs of children as possible were selected, one child from the combined group of dairy farmers and

Table IV

Nutritional status of pre-school children $(6-59 \mathrm{~m})$ by dairy group in Kilifi, Kenya (averages with standard deviation in brackets)

\begin{tabular}{lccc}
\hline & $\begin{array}{c}\text { Dairy } \\
\text { Farmers } \\
(N=44)\end{array}$ & $\begin{array}{c}\text { Dairy } \\
\text { Customers } \\
(N=39)\end{array}$ & $\begin{array}{c}\text { Rural } \\
\text { Sample } \\
(N=138)\end{array}$ \\
\hline Child age (months) & $33.4(14.8)$ & $27.9(16.6)$ & $34.3(16.1)$ \\
Height-for-age (\%) $^{(a)}$ & $93.7(5.0)$ & $94.5(6.6)$ & $91.7(10.0)$ \\
${\text { Weight-for-height }(\%)^{(b)}}^{(b)}$ & $94.2(4.0)$ & $94.4(7.4)$ & $91.8(11.5)$ \\
Weight-for-age (\%) $^{(\mathrm{c})}$ & $84.0(4.1)$ & $85.3(8.9)$ & $78.5(9.7)$ \\
\hline
\end{tabular}

(a) $F(2,218)=8.54 ; p=0.00$.

(b) $F(2,218)=2.44 ; p=0.09$.

(c) $F(2,218)=9.66 ; p=0.00$. 
TABLE V

Nutritional status of paired pre-school children $(6-59 \mathrm{~m})$ by dairy group in Kilifi, Kenya (averages with standard deviation in brackets)

\begin{tabular}{|c|c|c|}
\hline & $\begin{array}{l}\text { Dairy Farmers } \\
\text { and Customers } \\
\qquad(N=51)\end{array}$ & $\begin{array}{c}\text { Rural } \\
\text { Sample } \\
(N=51)\end{array}$ \\
\hline Height-for-age $(\%)^{(a)}$ & $93.9(4.7)$ & $92.3 \quad(3.2)$ \\
\hline Weight-for-height $(\%)^{(b)}$ & $94.7(5.8)$ & $91.3(8.0)$ \\
\hline Weight-for-age $(\%)^{(c)}$ & $84.7(9.1)$ & $79.4 \quad(9.3)$ \\
\hline Child age (months) & $33.5(14.8)$ & $34.7(14.3)$ \\
\hline Income/c.u. (sh.household/year) & $2,473(2,004)$ & $2,373(2,046)$ \\
\hline Energy intake (kcal/c.u.) & $2,482(962)$ & $2,994 \quad(846)$ \\
\hline Milk consumption/c.u. (g) & $137(108)$ & $(49)$ \\
\hline $\begin{array}{l}\text { Head household, more } \\
\text { than primary education }(\%)\end{array}$ & 16 & 12 \\
\hline
\end{tabular}

(a) paired $t$-test; $p=0.04$

(b) paired $t$-test; $p=0.02$.

(c) parred $t$-test; $p=0.004$.

customers $^{10}$ and one from the rural sample respectively. The pairs of children were matched for household income and drawn from the same age group (Table V). Holding household income constant in this way, also controls for educational level of household head while household energy intake is also eliminated since it is not higher among the combined group of dairy farmers and customers. Still, there remains a substantial difference in milk consumption. ${ }^{11}$ Differences between the combined group of dairy farmers-customers and the rural sample are significant for all anthropometric indicators which indicates a positive relation between milk consumption and nutritional status of children.

\footnotetext{
${ }^{10}$ From the results so far it is clear that the groups of dairy farmers and dairy customers show great similarities and the two groups were merged for this analysis.

${ }^{11}$ This method selects children from the same income range and effectively eliminates the higher incomes (from the first group) and the lower incomes (from the rural sample). This explains why the figures for milk consumption are lower than those in Table III.
} 


\section{DISCUSSION}

The present study tried to assess the importance of intensive dairy farming for the two groups of beneficiaries, dairy farmers and dairy customers. The data reported were collected ten years ago among the first group of participants in Kilifi District, but this does not detract from the relevance of the findings. The results of the latest national nutrition survey in 1987 (Kenya, 1991) do not show improvements in the coastal districts compared with 1982 (Kenya, 1983). Secondly, there is no reason to expect that since that time differential changes have affected the groups that were compared. The households that joined the project later had to meet the same requirements.

The economic risk of dairy farming is relatively high, in particular when the unit counts only few animals. In general it is unlikely that farmers will invest all their capital in intensive dairy farming; they need to reserve some capital for security. An evaluation of the original DDP demonstration farms all over Kenya confirmed this; of the farmers who had failed (30\%) the majority mentioned lack of capital as the main reason, and loss of animals next (Voskuil, 1986).

Fears generally exist that when dairy farming is commercialised, farmers will reduce the amount of milk kept for family consumption. Such trends were earlier observed in the hinterland of Kilifi and Kwale District as a result of the buying up by private milk traders and the Mariakani Milk Scheme (Gerlach, 1963), which has since been discontinued. The danger was also mentioned in connection with Operation Flood, the large dairy scheme in India (Doornbos et al., 1990). However, the objective of DDP was to create new production units, not to market milk from existing units and, in this case, the dairy farmers indeed kept 1.5-2.0 litres a day for home consumption.

The customers of DDP-farmers belonged mainly to a group of wage earners with relatively high and regular incomes. The local clients for DDP-milk consist of households with better paid jobs in the locations studied, either employed in the nonagricultural sector or by the government. The group has a larger number of infants. They and the dairy farmers often use milk as a drink for the children. 
The nutritional status of pre-school children among dairy farmers and dairy customers is better than that among children from the rural population. This difference was also shown to exist after household income was controlled for, confirming that higher and regular milk consumption has a distinct benefit under these rural conditions.

There are few customers among the main smallholder population, which confirms the existing insight that despite the benefits of milk consumption, it is not an important means to improve nutritional conditions among low income rural populations because of its costs (Netherlands, 1992). Milk is an expensive source of energy and protein and even when used as an ingredient, for example to add to maize to increase energy density, it is still more expensive than preparing a porridge of maize with beans. Aldeman (1994) also concluded that the milk consumption of the poor is very low and that milk marketed by rural producers is not taken away from this group.

Generally it is difficult to evaluate the nutritional effects of agricultural development in Sub-Saharan Africa. It is usually not possible to compare conditions before and after the start of projects. Either too much time has passed after the initial start, or too many extraneous variables have since come into play. Usually the remaining option is to compare participants in the project with nonparticipants. One persistent problem with this kind of study design is whether there were pre-existing differences between the groups at the start of the project which may partly or fully explain subsequently established differences. Multivariate analysis is often not possible due to the limitations of study designs and data.

In the present case it was known that the DDP-participants were, by definition, an atypical, selected group and the income differences with the rural sample consist of dairy income but also of income from crop cultivation and off-farm employment. Still, it was shown that the dairy farming clearly contributed a significant part of the income of the dairy farmers and that the higher milk consumption was related to better nutritional status of children. The fact that the dairy farmers at the same time had high incomes from off-farm employment seems to suggest that employ- 
ment income is not only needed to be able to start a DDP-farm but probably also helps to maintain the intensive dairy farming. This means that intensive dairy farming will stay out of reach for the majority of smallholders in coastal Kenya who do not have the means to start a dairy farm and who already have problems attaining a minimum livelihood.

\section{ACKNOWLEDGMENTS}

The research reported here was facilitated by the Ministry of Planning and National Development, Nairobi, and the African Studies Centre, Leiden, and was funded by the Netherlands Ministry of Development Cooperation. The authors wish to acknowledge the support of Mr. J. Ochuonyo and Ir. H. van Slooten of the Ministry of Livestock. We wish to thank Mr. J. Ngolo, field supervisor of the Central Bureau of Statistics, for his invaluable assistance. Harold van Driel, Wijnand Klaver and Rudo Niemeijer assisted during different stages of the analysis.

\section{REFERENCES}

Aldeman, H. (1994). Why should it matter what commodity is the source of profit. In J. von Braun and E. Kennedy (Eds.), Agricultural Commercialization, Economic Development and Nutrition. Johns Hopkins University Press, Baltimore, pp. 239-251.

Boxem, H.W., T. de Meester and E.M.A. Smaling (1987). Soils of the Kilifi Area. Centre for Agricultural Publishing and Documentation (Pudoc), Wageningen.

Braun, J. von and E. Kennedy, Eds. (1994). Agricultural Commercialization, Economic Development and Nutrition. Johns Hopkins University Press, Baltimore.

Doornbos, M., F.V. Dorsten, M. Mitra and P. Terhal (1990). Dairy Aid and Development. India's Operation Flood (Indo-Dutch Studies on Development Alternatives; 3). Sage, New Delhi/London.

Fleuret, P. and A. Fleuret (1980). Nutrition, Consumption and Agricultural Change. Human Org., 39, 250-260.

Gerlach, L.P. (1963). Traders on bicycle: A study of entrepreneurship and culture change among the Digo and Duruma of Kenya. Sociologus (Berlin), 13(1), 32-49. 
Greer, J. and E. Thorbecke (1986). Food Poverty and Consumption Patterns in Kenya. International Labour Office, Geneva.

Herlehy, T.J. (1984). An Historical Dimension of the Food Crisis in Africa: Surviving famines along the Kenya Coast, ca.1880-1980. Working Paper no. 87, African Studies Center, Boston University, Boston, Mass.

Hoorweg, J., R. Niemeijer, D. Foeken, W. Okello and W. Veerman (1991). Economic and Nutritional Conditions at Settlement Schemes in Coast Province. Ministry of Planning and National Development/African Studies Centre, Food and Nutrition Studies Programme, Report no. 36, Nairobi/Leiden.

Hoorweg, J. (1993). FNSP Studies, 1985-1992: Results and recommendations. Ministry of Planning and National Development/African Studies Centre, Food and Nutrition Studies Programme, Report no. 50, Nairobi/Leiden.

Hoorweg, J., D. Foeken and W. Klaver (1995). Seasons and Nutrition at the Kenya Coast. ASC Research Series 7. Avebury: Oxford.

Hoorweg, J., D. Foeken, W. Klaver, W. Okello and W. Veerman W (1996). Nutrition in Agricultural Development: Land settlement in Coast Province, Kenya, Ecol. Food Nutr., 35, 161-178.

Jaetzold, R. and H. Schmidt (1983). Farm Management Handbook of Kenya, vol II: Natural conditions and farm management information; Part C: East Kenya. Ministry of Agriculture, Nairobi.

Kenya, Republic of (1981). The Integrated Rural Surveys, 1976-1979: Basic report. Central Bureau of Statistics, Nairobi.

Kenya, Republic of (1983). Third Rural Child Nutntıon Survey, 1982. Central Bureau of Statistics, Nairobi.

Kenya, Republic of (1984a). Kilifi District Environmental Assessment Report. Ministry of Environment and Natural Resources, Nairobi.

Kenya, Republic of (1984b). Kwale District Environmental Assessment Report. Ministry of Environment and Natural Resources, Nairobi.

Kenya, Republic of (1986a). Annual Report 1985, Kilifi District. Ministry of Agriculture and Livestock Development, Kilifi.

Kenya, Republic of (1986b). Sessional Paper No. 1 on Economic Management for Renewed Growth. Government of Kenya, Nairobi.

Kenya, Republic of (1988). Economic Survey-1988. Central Bureau of Statistics, Nairobi.

Kenya, Republic of (1991). Fourth Rural Chld Nutrition Survey 1987. Central Bureau of Statistics, Nairobi.

Kenya, Republic of (1994). Kenya Population Census, 1989: Volume 1. Central Bureau of Statistics, Nairobi.

Kliest, T. (1985). Regional and Seasonal Food Problems in Kenya. Ministry of Planning and National Development/African Studies Centre, Food and Nutrition Studies Programme, Report no. 10, Nairobi/Leiden.

Kubo-Hoorweg, A.M. (1999). Personal communication, confirmed by field observations of the first author.

Leegwater, P., J. Ngolo and J. Hoorweg (1991). Nutrition and Darry Development in Kilifi District. Ministry of Planning and National Development/African 
Studies Centre, Food and Nutrition Studies Programme, Report no. 35, Nairobi/Leiden.

Leegwater, P. and J. Hoorweg. Dairy development. In J. Hoorweg, D. Foeken and R. Obudho (Eds.), Kenya Coast Handbook. LTT Verlag (in press), Hamburg.

Mwangi, Z.J., B.L.M. van Woersem, R.O. Mosi and A. Bootsma (1986). Report of the Third joint Kenya/Netherlands Evaluation Mission on the Dairy Development Programme. Government of Kenya/Government of the Netherlands, Nairobi/The Hague.

Netherlands, Government of the (1992). Livestock Production in Developing Countries. Ministry of Foreign Affairs, Development Cooperation, sGravenhage.

Niemeijer, R., M. Geuns, T. Kliest, V. Ogonda and J. Hoorweg (1988). Nutrition in agricultural development: The case of irrigated rice cultivation in West Kenya. Ecol. Food Nutr., 22, 65-81.

Niemeijer, R., D. Foeken and W. Klaver (1991). Seasonality in the Coastal Lowlands of Kenya. Part 4/5: Food consumption and anthropometry. Ministry of Planning and National Development/African Studies Centre, Food and Nutrition Studies Programme, Report no. 38, Nairobi/Leiden.

Oosten, C. van (1989). Farming Systems and Food Security in Kwale District, Kenya. Ministry of Planning and National Development/African Studies Centre, Food and Nutrition Studies Programme, Report no. 30, Nairobi/ Leiden.

Pinstrup-Andersen, P. (1985). The impact of export crop production on human nutrition. In M. Biswas and P. Pinstrup-Andersen (Eds.), Nutrition and Development. Oxford University Press, Oxford, pp. 43-59.

Platt, B.S. (1962). Tables of Representative Values of Foods Commonly used in Tropical Countries (revised Ed.). Medical Research Council Special Report no. 302, Her Majesty's Stationery Office, London.

Ruigu, G.M. (1987). Large-Scale Irrigation Development in Kenya: Past performance and future prospects. Ministry of Planning and National Development/ African Studies Centre, Food and Nutrition Studies Programme, Report no. 23, Nairobi/Leiden.

UNICEF (1984). Situation Analysis of Children and Women in Kenya, vol. 4. The well-being of children. Central Bureau of Statistics/UNICEF, Nairobi.

Valk, Y.S. van der (1985). Economics of Zero-Grazing. Paper prepared for: Symposium on 'Zero-Grazing for Milk Production' of the Animal Production Society of Kenya, Kabete, November 1985, Nairobi. Ministry of Agriculture and Livestock Development, Dairy Development Project, Nairobi.

Voskuil, G.C.J. (1986). Report on the Original Demonstration Farms. Ministry of Agriculture and Livestock Development, Dairy Development Project, Nairobi.

Waaijenberg, H. (1993). Land and Labour in Mijikenda Agriculture, Kenya, 1850-1985. African Studies Centre, Research Report no. 53, Leiden.

Waaijenberg, H. (1994). Mijikenda Agriculture in Coast Province of Kenya: Peasants in between tradition, ecology and policy. Royal Tropical Institute, Amsterdam. (Ph.D. thesis. University of Wageningen). 
WHO (1983). Measuring Change in Nutritional Status: Guidelines for assessing the nutritional impact of supplementary feeding programmes for vulnerable groups. World Health Organization, Geneva.

WHO (1985). Energy and Protein Requirements. World Health Organization, Technical report 724, Geneva. 